\title{
eTV's faith healing advertorial 'fatal' - TAC
}

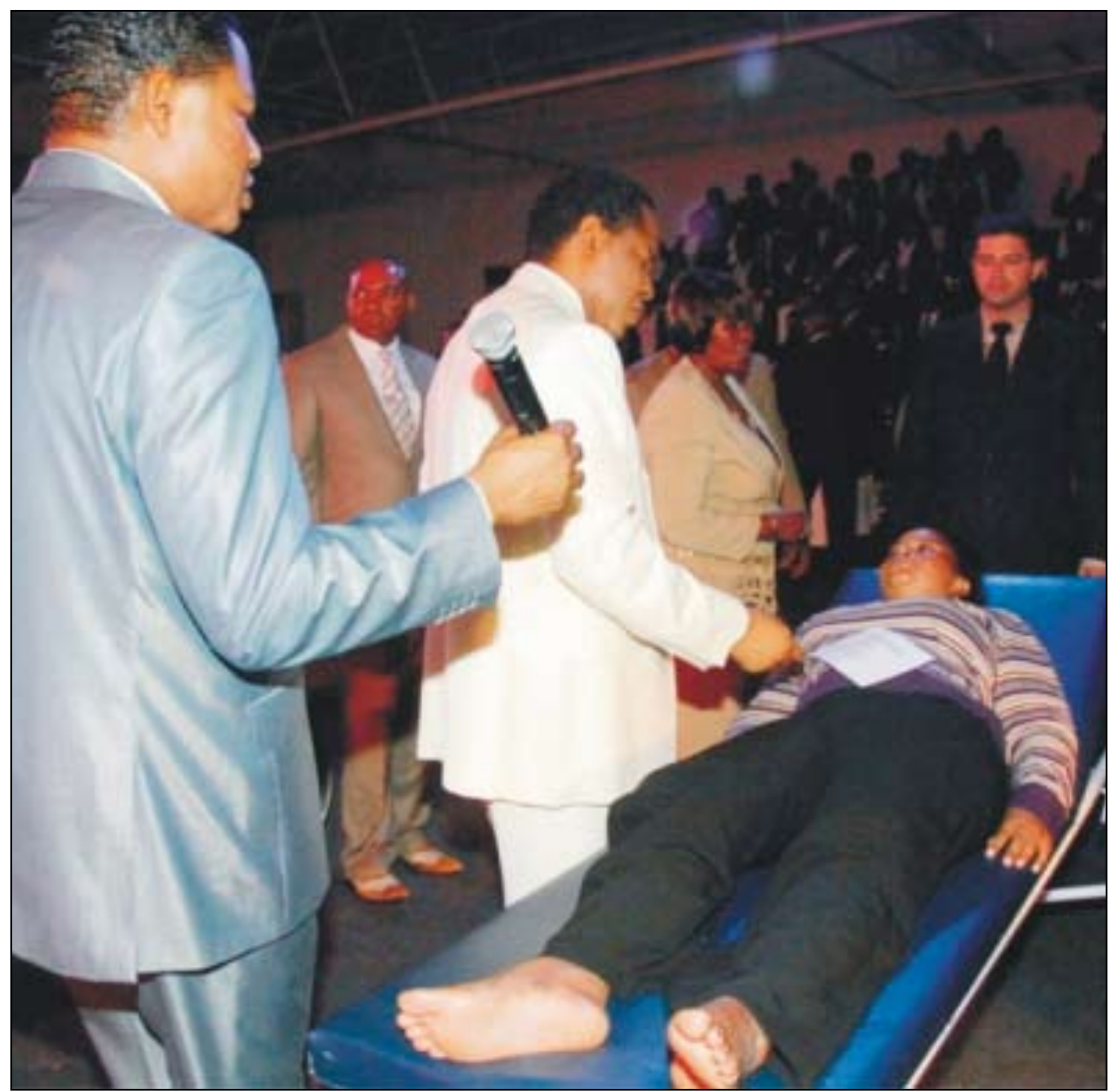

Pastor Chris Oyakhilome (in white), of the Christ Embassy Healing School, in action.

Appeals last month by the Treatment Action Campaign (TAC) to eTV's 'sense of ethics and morality' to enable the canning of a 22-minute commercial programme that promotes demonstrably fatal faithhealing were studiously ignored, the organisation claims.

In the 'Christ Embassy Healing School' advertorial (aired at $07 \mathrm{~h} 30$ on Sundays), its head, Pastor Chris Oyakhilome, claims he can faith-heal cancer, heart disease and arthritis. The church's website includes HIV/ AIDS in its list of curable life-threatening conditions. At least two HIV-positive people died last year after attending Christ Embassy 'healing' services in Johannesburg, 'faithfully' stopping their ARV treatment, one of them also infecting family members with multidrug-resistant $\mathrm{TB}$, it has since emerged.

TAC veteran activist and treasurer, Nathan Geffen, produced a doctor and senior nurse who worked at the GF Jooste district hospital on the Cape Flats last year and treated a young HIV-positive mother. Dr Graham
Meintjes, now working at the University of Cape Town's medical school, said he treated the woman for HIV over a period of $2^{1 / 2}$ years at GF Jooste Hospital. She had 'done exceptionally well', gaining $22 \mathrm{~kg}$ with her CD4 cell count back up and TB cleared from her sputum. When she told him that she had attended a Christ Embassy 'curing ceremony' in Johannesburg, he immediately appealed to her to keep taking her medicines. She had agreed. However, feedback to him from her friends in the community was that she honestly believed she was cured. Near the end of last year she returned to hospital with advanced AIDS and disseminated TB. In spite of restarting medication she remained bed-ridden and critical and died soon after admission. Meintjes said the public health dangers of such charlatan outfits were further graphically illustrated when he later discovered that his patient had transmitted drug-resistant TB to her family members.

Nursing sister Priscilla Mouton, who worked alongside Meintjes, fought back tears as she related how she had befriended the
Nursing sister Priscilla Mouton, who worked alongside Meintjes, fought back tears as she related how she had befriended the woman and tried to phone her

to persuade her to return to hospital.

woman and tried to phone her to persuade her to return to hospital. The last time she saw her was at a taxi rank. 'I was shocked at her condition. She brushed off my appeals, saying she was $\mathrm{OK}$... she was a mother who loved her children dearly. If she'd continued taking those treatments she'd be with us today', she said. Mouton claimed to know of at least one other person who attended Christ Embassy 'healing' sessions and who died after stopping his ARVs.

Meintjes said a 'critical aspect' of the controversy was that the media broadcast an 'evidence-based approach' and not spread messages that misled people. A visit to Christ Embassy's website reveals it to be 'the world's largest digital media marketplace, touting e-books, mp3 messages, music, audio books, e-videos and podcasts with 'special offers' and 'e-devices'. It includes nearly a dozen generic links to topics such as 'Prosperity and Finance', 'Leadership and Discipleship' and 'Salvation and Evangelism'.

\section{ASASA said eTV's compliance executive had 'clarified' for them that the material was a religious programme, classified as 'advertiser-funded'.}

The Advertising Standards Authority of South Africa (ASASA)'s response to an official TAC complaint made in November was that the programme (which it had viewed) came under the definition of 'programming material', and therefore fell outside their jurisdiction. ASASA said eTV's compliance executive had 'clarified' for them that the material was a religious programme, classified as 'advertiser-funded'. It referred all further debate on the respondents' claims to the Broadcasting Complaints Commission of South Africa, but confirmed that an appeal lodged with it by the TAC would be heard at the end of August. In a subsequent press statement, eTV said it had received no further correspondence from ASASA 
on the matter and would continue airing the programme, known as 'Higher Life'. It stressed that it had included a disclaimer before, during and after the programme, stating that it was an advertorial and that 'the opinions and views expressed' were not necessarily the same as those held by eTV.

\section{However, by waiting for an} ASASA appeal ruling, eTV was avoiding the issue and knowingly continuing to promote quackery. 'We've appealed to their sense of ethics and sense of morality, but they're still refusing,' Geffen said.

Geffen and Meintjes acknowledged that eTV had also run several programmes exposing 'quackery' and stressed that they in no way wanted their objections to be viewed as part of the current 'concerted attack on the media by government' or an attack on faith per se. 'Our concern is around the specific public health consequences of Christ Embassy's actions. Religious groups generally help raise AIDS awareness and provide spiritual and emotional support and adherence. Their contribution is normally vast and their partnership essential,' Geffen added. However, by waiting for an ASASA appeal ruling, eTV was avoiding the issue and knowingly continuing to promote quackery. 'We've appealed to their sense of ethics and sense of morality, but they're still refusing, Geffen said.

The Reverend Sidney Williams of the AME Church in Cape Town asked Geffen how he reconciled Christ Embassy's lack of 'doctrinal or specific' statements against medicine with individual choice. Geffen said the problem was implicit in Christ Embassy's message. 'There are many situations in which patients decide not to take treatment ... they have that individual liberty. Our problem is with large organisations making lots of money spreading messages that they have miracle cures.'

Geffen later told Izindaba that while he fully supported patients' right to choose, he did not believe 'suppliers' had such rights. 'One cannot offer whatever one chooses. If I buy a car and it doesn't work, I can get relief from the car salesman. If I am advised badly by a financial advisor, I can take legal action against him. Surely the same logic should apply, even more compellingly, when it comes to medicine?' he argued.

Professor Ames Dhai, Director of the Steve Biko Centre for BioEthics at the University of the Witwatersrand, told Izindaba that the low levels of education in South Africa were a vital social determinant of health and prevented people from making informed choices. 'We can only properly exercise our right to autonomous decision (contained in Section 12 of the Bill of Rights) and the right to bodily and psychological integrity, if we have adequate, well-balanced information. Surely eTV has some accountability to these patients that go downhill and the families that lost them? Its general management really needs to look at their ethics', she added.

In July this year ASASA ruled against the Solid Rock Church which claimed (in an advert in the weekly Northcliff/Melville Times) to be able to cure the blind, the lame, AIDS and cancer victims, adding ' 43 crutches! 25 walking sticks, 2 white canes from blind people! Already left behind!' Calling itself the 'Church of Miracles', it was twice sanctioned by the ASASA for the same adverts and was this July found to be in breach of the previous rulings. The ASASA instructed the church to 'immediately and permanently' remove the advert from all media in which it appeared and gave the church until 20 August to comment on further proposed sanctions.

Chris Bateman 